\title{
Germination of Pomegranate Seeds under Sarcotesta Extraction Methods and Drying
}

\author{
Deived U. de Carvalho ${ }^{1}$, Maria A. da Cruz ${ }^{1}$, Elisete A. F. Osipi ${ }^{2}$, Jethro B. Osipe ${ }^{2}$, Ronan C. Colombo ${ }^{1}$, \\ Jéssica de L. Marinho ${ }^{1}$, Maria A. F. Sorace ${ }^{2}$ \& Conceição A. Cossa ${ }^{2}$ \\ ${ }^{1}$ Agricultural Science Center, Londrina State University, Londrina, Brazil \\ ${ }^{2}$ Departament of Agronomy, Northern Paraná State University, Bandeirantes, Brazil \\ Correspondence: Deived U. de Carvalho, Agricultural Science Center, Londrina State University, Londrina, PR \\ Pr-445 Km-380, Brazil. Tel: 55-043-3371-4697. E-mail: deived10@gmail.com
}

Received: July 10, 2017

Accepted: August 16, 2017

Online Published: September 15, 2017

doi:10.5539/jas.v9n10p198

URL: https://doi.org/10.5539/jas.v9n10p198

\begin{abstract}
Aiming to evaluate the effect of degumming methods and natural drying, as well as, the influence of different periods of seeds in quicklime solution on Punica granatum L. germination, were conducted two experiments. At first, the seeds from ripe fruits were subjected to the following sarcotesta extraction: natural fermentation at room temperature, during 72 hours; immersion in quicklime $(\mathrm{CaO})$, during 24 hours; and non-degumming, taken as control. For the second experiment, the extraction method was carried out by the following mixture: seeds, quicklime, and distilled water; differing the immersion period $(5,10,15,20$, and 25 hours). In both, the experimental design was completely randomized, performing the water content and germination test. The quicklime method is efficient to degrade and to eliminate the sarcotesta on P. granatum seeds, and the drying process provides a better germination. In addition, there is a linear increase on seed physiological quality when upgrades the immersion period in quicklime solution.
\end{abstract}

Keywords: Punica granatum L., propagation, degumming, drying

\section{Introduction}

The pomegranate (Punica granatum L.) is a woody shrubby plant, native from Iran and Himalaya region. It presents spherical fruits and seeds involved by pulpy sarcotesta (Ferreira, 2004). The species has several therapeutic properties, which awakes the interest of the pharmaceutical and food industry (Werkman et al., 2008).

In commercial scale, the pomegranate propagation is performed by seeds (Kanwar et al., 2010; Batista et al., 2011). However, germination problems are commonly found in several species. For this specie, have been reported problems as propagation that are influenced by the seed dormancy, which causes desuniformity and unsatisfactory seedlings establishment (Materechera \& Seeiso, 2013). Similarly, others factors can affect the germination such as the seed sarcotesta, which can persist adhered on the seeds. This effect was confirmed in seeds of Passiflora edulis (Martins et al., 2010) and Carica papaya (Melo \& Seleguini, 2013). In this way, to preserve the physiological seed quality in order to obtain the maximum germination, emergence and seedling uniformity, the sarcotesta must be removed adequately (Cardoso, 2011).

Several procedures can be applied as a method to eliminate the sarcotesta to improve the germination rates, but few studies concern pomegranate (Lopes et al., 2001; Olmez et al., 2007; Gokturk et al., 2012). Among the extraction methods, the fermentation process is commonly utilized for quite a few species. Studies about pomegranate have shown an increase on seedlings vigor originated from seeds submitted to 72 hours of fermentation (Lopes et al., 2001). Others treatments as quicklime $(\mathrm{CaO})$, can also be used to eliminate the mucilage from fleshy fruits (Silva, 2012). This technique has been investigated by several authors in different species (Martins et al., 2006; Freitas et al., 2011; Osipi et al., 2011; Aguiar et al., 2014; Santos-Moura et al., 2014; Araújo et al., 2015); but, at the same time, its effect on pomegranate seeds still unknown.

As far as the sarcotesta extraction methods is concerned, the drying process knowledge is necessary to maintain the seed quality. However, it needs to be conducted adequately, depending of the moisture levels of each species requirement and the method utilized, it can be harmful to ensure the seed quality or even unusable the seeds 
during the storage (Carvalho \& Nakagawa, 2012). Under these circumstances, it is required to conduct investigations to clarify the effect of drying process for pomegranate seeds compared to the different methods of sarcotesta extraction, emphasizing to the dormancy caused by the seed coat (Silva, 2013). Therefore, aiming to evaluate the effect of three degumming methods, associated or not to the natural drying; as well as the influence of different periods of seeds in quicklime solution on germination of $P$. granatum, there were conducted two experiments.

\section{Materials and Methods}

Two experimental tests were conducted at the Seed Analysis Laboratory of the Northern Paraná State University, Bandeirantes, Brazil.

\subsection{Experiment I}

For the first experiment, there were used 12 ripe fruits from different plants. The seeds were manually removed from the fruits, divided into three equal parts and submitted to different methods of sarcotesta extraction.

In the first method, the seeds were fermented in sugar solution (10\%) during 72 hours, at room temperature. The second, consisted in addition of quicklime $(\mathrm{CaO})$ and distilled water on the seeds, placed inside a Becker until complete mixture in volumetric proportions of 3:2:5, respectively. The seeds reposed for 24 hours in this solution. Also, there was performed a treatment as control: the seeds were not submitted to degumming process, remaining with the sarcotesta.

After each method, the seeds were washed on steel sieve under running water for two minutes. Then, each part was divided into two portions, one was laid on absorbent sheet to dry out at room temperature during three days, and the other portion was immediately carried the germination test out.

The determination of seed moisture content was performed utilizing the oven method at $105 \pm 3{ }^{\circ} \mathrm{C}$ during 24 hours (Brasil, 2009), using four replicates of 100 seeds per treatment and the results were expressed as percentage. The germination test was performed on Germitest ${ }^{\mathbb{R}}$ paper, light absence and alternated temperature of $20-30{ }^{\circ} \mathrm{C}$ (8-16 hours), utilizing four samples of 25 seeds per treatment, previously immersed in fungicide suspension of metalaxyl-m + fluodioxonil (Maxim XL ${ }^{\circledR}$ ) $0.2 \%$ for three minutes.

The evaluations were performed at 7, 14, 21, 28 and 35 days after sowing by counting germinated seeds, considering those with radicle length equal or greater than two millimeters. From these data, there were evaluated weekly percentages of germinated seeds and at 35 days after sowing, when occurred the germination stabilization, there were counted the total of germination percentage and germination speed index (GSI) based in the Maguire's formula (1962), as well as, the percentage of normal seedlings, abnormal seedlings, and dormant seeds (Brasil, 2009). The experimental design was completely randomized in a factorial design of $3 \times 2$, combining three degumming methods of seeds submitted or not to dry.

\subsection{Experiment II}

For the second experiment, there were used 12 mature fruits from different plants. The degumming method was carried out by the mixture of seeds, quicklime $(\mathrm{CaO})$ and distilled water $(5: 3: 2$, respectively), varying in 5,10 , 15,20 and 25 hours the time that the seeds were laid in the solution. After each period, the seeds were washed on sieve under running water for two minutes and placed on absorbent sheet to dry out, during three days. The seed moisture content and the germination test were performed similarly to the previous experiment. The experimental design was completely randomized using five treatments $(5,10,15,20$, and 25 hours) and four samples of 50 seeds.

All data were submitted to ANOVA, and means compared by Tukey's test at 0.05 of probability (Experiment $I$ ) and by polynomial regression (Experiment II). The data, when necessary, were transformed to arcsin $((\mathrm{x} / 100)$ $1 / 2)$.

\section{Results and Discussion}

\subsection{Experiment $I$}

The interaction between extraction methods and drying was not significant for the characteristics analyzed at the Table 1, indicating that the factors act independently. On the other hand, the factors were dependent for percentage of normal seedlings (Table 2), occurring an interaction between them. 
Table 1. Total of germination percentage $(G)$, germination speed index (GSI), normal seedlings (NS), dormant seeds (DS) of $P$. granatum L. seeds under sarcotesta extraction methods and drying at 35 days after sowing

\begin{tabular}{lllll}
\hline Treatments & G $(\%)$ & GSI & NS (\%) & DS (\%) \\
\hline Quicklime $(\mathrm{CaO})$ & $70 \mathrm{a}$ & $4.44 \mathrm{a}$ & $52 \mathrm{a}$ & $30 \mathrm{~b}$ \\
Fermentation & $10 \mathrm{~b}$ & $0.18 \mathrm{~b}$ & $2 \mathrm{~b}$ & $90 \mathrm{a}$ \\
Control & $5 \mathrm{~b}$ & $0.39 \mathrm{~b}$ & $1 \mathrm{~b}$ & $95 \mathrm{a}$ \\
\hline Drying & $35 \mathrm{~A}$ & $1.97 \mathrm{~A}$ & $23 \mathrm{~A}$ & $65 \mathrm{~B}$ \\
No Drying & $21 \mathrm{~B}$ & $1.37 \mathrm{~B}$ & $14 \mathrm{~B}$ & $79 \mathrm{~A}$ \\
\hline SMD $_{\text {Extraction Methods }}$ & 12.59 & 1.81 & 10.81 & 12.68 \\
SMD & 8.45 & 1.22 & 7.26 & 8.52 \\
CV $(\%)$ & 21.36 & 26.18 & 20.44 & 11.06 \\
\hline
\end{tabular}

Note. ${ }^{*}$ Means followed by the same letters in the column do not differ statistically by Tukey's test at 0.05 .

Table 2. Abnormal seedlings percentage of $P$. granatum L. seeds under sarcotesta extraction methods and drying at 35 days after sowing

\begin{tabular}{lll}
\hline Treatments & Drying & No Drying \\
\hline Quicklime $(\mathrm{CaO})$ & $16 \mathrm{aA}$ & $18 \mathrm{aA}$ \\
Fermentation & $16 \mathrm{aA}$ & $0 \mathrm{bB}$ \\
Control & $6 \mathrm{aB}$ & $1 \mathrm{bB}$ \\
\hline $\mathrm{SMD}_{\text {Lowercase (column) }}$ & 8.12 & \\
$\mathrm{SMD}_{\text {Uppercase (row) }}$ & 6.68 & \\
$\mathrm{CV}(\%)$ & 36.35 & \\
\hline
\end{tabular}

Note. ${ }^{*}$ Equal letters, lowercase in the row and uppercase in the column, do not differ by Tukey's test at 0.05 .

The quicklime method highlighted compared to the others, providing better results with $70 \%$ of germinated seeds, 4.44 of germination speed index (GSI), and 53\% of normal seedlings, representing $75 \%$ from the total of germination percentage at 35 days. This treatment promoted a faster and more uniform germination at the first week, while the others just started at 7-14 days after sowing (data not shown). It is noted that the control and the fermentation method did not accelerate or increase germination, germination speed index, and normal seedlings as occurred for the quicklime method; but in contrast, it provided a substantial percentage of dormant seeds (Table 1).

Investigations regarding sarcotesta extraction, as quicklime method, on pomegranate seeds do not exist in the literature. However, studies on other species have shown positive results (Martins et al., 2006; Osipi et al., 2011; Aguiar et al., 2014; Araújo et al., 2015). Similarly, Silva (2012) relates that this method promotes a chemical seed scarification causing the breakage and abrasion of the sarcotesta, which increase the water permeability and germination, as seen in this study.

Among the quicklime method to degum seeds, there are manual friction with quicklime on sieve under running water for Passiflora edulis (Pereira \& Dias, 2000; Aguiar et al., 2014), Jacaratia spinosa (Freitas et al., 2011), Hylocereus undatus (Alves et al., 2012) or seed immersion in quicklime solution for P. edulis (Martins et al., 2006) and Passiflora alata (Osipi et al., 2011), during 10 minutes.

Furthermore, the low values in seed quality for the fermentation method were similar to those observed by Lopes et al. (2001), where the pomegranate seeds subjected to 72 hours of fermentation and subsequent drying, exhibited emergency percentage and emergence speed index (20\% and 0.2 , respectively), much lower than those obtained by fermentation and no drying.

The fermentation process has also brought conflicting results when used to remove the seeds mucilage from other species. In this way, Pereira and Dias (2000), Martins et al. (2006) and Aguiar et al. (2014) observed that fermentation did not influence the germination of $P$. edulis seeds, as observed in this study. Conversely, São José and Nakagawa (1987) noticed that extraction by fermentation method improved the quality of $P$. edulis seeds.

Regardless the extraction methods, drying seeds provided higher germination percentage, germination speed index, and normal seedlings (Table 1) compare to those that were not subject to this process. Marcos Filho (2015) reported that drying is one of the factors that can affect the seed quality during the production process, because 
the reduction of the water content acts slowing down the metabolism, contributing to reduce the deterioration rate and increase the storage period, without loss on physiological quality.

For the characteristics seed water content, fresh and dry matter of 100 seeds (Table 3), it was observed an interaction between the factors. Independently of drying, the sarcotesta presents on the control seeds provided higher fresh and dry matters, and the highest water content when submitted to dry. This effect might indicate that the seeds that were not submitted to sarcotesta extraction could absorb moisture from the air, instead losing to the ambient during the drying process.

Table 3. Seed water content (\%), fresh and dry matter of 100 seeds (g) in P. granatum L. seeds under sarcotesta extraction methods and no drying (ND) and drying (D) before sown

\begin{tabular}{|c|c|c|c|c|c|c|}
\hline \multirow{2}{*}{ Extraction Methods } & \multicolumn{2}{|c|}{ Seed Water Content (\%) } & \multicolumn{2}{|c|}{ Fresh Matter of 100 Seeds (g) } & \multicolumn{2}{|c|}{ Dry Matter of 100 Seeds (g) } \\
\hline & ND & $\mathrm{D}$ & ND & $\mathrm{D}$ & ND & $\mathrm{D}$ \\
\hline Quicklime $(\mathrm{CaO})$ & $37 \mathrm{aB}$ & $11 \mathrm{bB}$ & $3.44 \mathrm{aC}$ & $2.45 \mathrm{bB}$ & $2.16 \mathrm{aB}$ & $2.17 \mathrm{aB}$ \\
\hline Fermentation & $57 \mathrm{aA}$ & $11 \mathrm{bB}$ & $5.15 \mathrm{aB}$ & $2.49 \mathrm{bB}$ & $2.21 \mathrm{aB}$ & $2.21 \mathrm{aB}$ \\
\hline Control & $39 \mathrm{bB}$ & $72 \mathrm{aA}$ & $7.54 \mathrm{bA}$ & $13.90 \mathrm{aA}$ & $4.59 \mathrm{aA}$ & $3.86 \mathrm{bA}$ \\
\hline SMD Extraction Methods & 2.48 & & 0.39 & & 0.17 & \\
\hline SMD $_{\text {Drying/No Drying }}$ & 2.04 & & 0.32 & & 0.14 & \\
\hline CV (\%) & 3.62 & & 3.72 & & 3.31 & \\
\hline
\end{tabular}

Note. ${ }^{*}$ Equal letters, lowercase in the row and uppercase in the column, do not differ by Tukey's test at 0.05 probability level.

The water content provided by quicklime and fermentation methods without drying differ statistically, which the fermentation shows the highest value. After drying, both became equal and differed from the control. The results are in agreement with Lopes et al. (2001), whom reported high water content $(80 \%)$ in pomegranate seeds under fermentation and no drying, decreasing the water content when it was submitted to dry $(20 \%)$.

Moreover, Materechera and Seeiso (2013) submitting the pomegranate seeds to different scarification techniques reported that drying process and sulfuric acid treatment promoted, significantly, higher water imbibition (9.6 versus $\left.17.8 \mathrm{~mm} \mathrm{~h}^{-1}\right)$ and germination percentage (25 versus 68\%) compared to fresh seeds. They also observed a significant correlation $(\mathrm{r}=0.83, \mathrm{p}<0.01)$ between water imbibition and germination, describing that seed treatments strengthen both. In this sense, the use of quicklime in this study provided analogous results to those obtained by Materechera and Seeiso (2013).

Similar to this study, the low germination or emergence percentage promoted by the control (presenting sarcotesta) was also observed in other species; such as, Eugenia jambolana, 18\% (Araújo et al., 2015); Carica papaya, 24\% (Melo \& Seleguini, 2013); and P. alata, 6\% (Osipi et al., 2011). This may indicate that the substances compounding the sarcotesta or aryl inhibit the seed germination. Several studies can confirm those substances in some species, including Talisia esculenta (Alves et al., 2009); P. edulis (Martins et al., 2010); P. alata (Osipi et al., 2011); C. papaya (Melo \& Seleguini, 2013); and E. jambolana (Araújo et al., 2015).

Martins et al. (2010) using extract from $P$. edulis aryl associated to dichloromethane and tween, obtained a reduction in the Lactuca sativa germination and high percentage of dormant seeds, presenting similar means to those noticed in here when the sarcotesta was not removed from the seeds (Table 1). The authors believe that some substances presenting in the extract may have contributed to inhibit the germination process, as can be seen by the high percentage of non-germinated seeds exposed to negative water potentials. It did not allow the water absorption due to the presence of hydrophobic molecules, such as, unsaturated triglycerides that build a barrier against the absorption. Also, they report the possibility of the steroids presence, which are substances that can act as hormones or can unbalance it, competing to the active site and/or inhibiting the action of essential hormones.

For the abnormal seedlings (Table 2), the extraction methods using fermentation associated to drying and quicklime presented the highest percentage. The quicklime was not influenced by the drying process, since there was not observed statistical difference for this factor. In contrast, it is noticed that drying affects negatively the seeds from fermentation method as those without degumming, providing higher percentage of abnormal seedlings. Concerning to the fermentation method, the results corroborate to Lopes et al. (2001) observing that drying seed at laboratory during nine days, promoted a reduction on viability and vigor of $P$. granatum seeds. 


\subsection{Experiment II}

By the regression analysis, the moisture content and dry matter of 100 seeds were not influenced by the different periods (hours) in quicklime solution. On the onther, threre was observed a linear increase on germination percentage and germination speed index (Figure 1), and those that remained immersed for 25 hours presented elevate germination speed index (5.89) and germination percentage (73\%). There was a similar effect on normal seedlings (Figure 2), obtaining an increase of 1.01 for each hour in quicklime solution reaching the highest percentage at 25 hours of immersion (65\%).

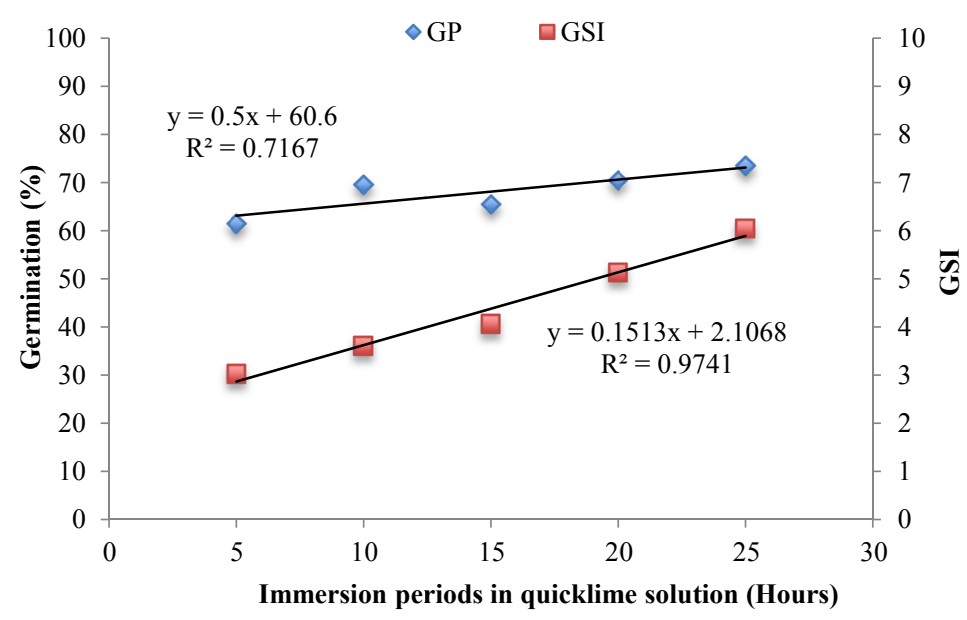

Figure 1. Germination percentage (GP) and germination speed index (GSI) of P. granatum L. seeds, submitted to different periods in quicklime solution

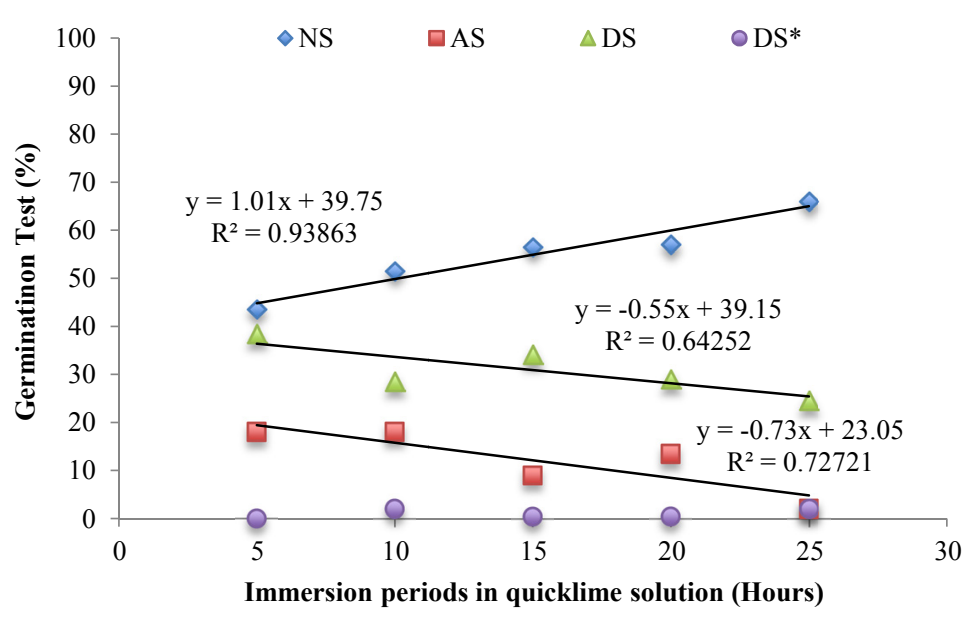

Figure 2. Percentage of normal seedling (NS), abnormal seedlings (AS), dormant seeds (DS), and dead seeds (DS*) of $P$. granatum L. seeds submitted to different periods in quicklime solution

The percentage of abnormal seedlings and dormant seeds reduced, when increased the immersion period in quicklime solution. It is noted that each period was equivalent to decrease 0.55 of abnormal seedlings and 0.51 of dormant seed. This is probable that if the seeds remain in quicklime solution for more hours, we can achieve a higher germination percentage due to quicklime efficiency on removing the sarcotesta and 'break' the dormancy. However, more investigations can be performed to elucidate this. The dead seeds percentage was not influenced by the quicklime treatment.

Considering the interval of five to 25 hours, it can be observed a linear increase in the physiological quality of pomegranate seeds, occurring an improvement when increased the immersion period. This effect was also 
observed by Cardoso et al. (2001), Lopes et al. (2001), Alves et al. (2009) and Santos-Moura et al. (2014) testing different fermentation period on germination and emergence of different species.

As well as, the quicklime treatment was studied in this experiment, the fermentation was efficient to degrade and eliminate the sarcotesta on P. granatum (Lopes et al., 2001), P. edulis (Cardoso et al., 2001), T. esculenta (Alves et al., 2009), and Crataeva tapia (Santos-Moura et al., 2014) seeds, promoting greater seed vigor and seedling emergence in a short period of time.

\section{Conclusion}

The quicklime method associated to drying, for three days, is efficient to degrade and to eliminate the sarcotesta on Punica granatum L. seeds, promoting better physiological quality. Also, there is observed a linear increase on germination percentage, normal seedlings, and germination speed index when upgrades the immersion period in quicklime solution until 25 hours.

\section{References}

Aguiar, R. S., Yamamoto, L. Y., Preti, E. A., Souza, G. R. B., Sbrussi, C. A. G., Oliveira, E. A. P., ... Neves, C. S. V. J. (2014). Extração de mucilagem e substratos no desenvolvimento de plântulas de maracujazeiro-amarelo. Semina: Ciências Agrárias, 35, 605-612. http://dx.doi.org/10.5433/1679-0359.2014 v35n2p605

Alves, C. Z., Godoy, A. R., \& Oliveira, N. C. (2012). Efeito da remoção da mucilagem na germinação e vigor de sementes de Hylocereus undatus Haw. Brazilian Journal of Agricultural Sciences, 7(4), 586-589. http://dx.doi.org/10.5039-agraria.v7i4a1750

Alves, E. U., Silva, K. B., Gonçalves, E. P., Cardoso, E. A., \& Alves, A. U. (2009). Germinação e vigor de sementes de Talisia esculenta (St. Hil) Radlk em função de diferentes períodos de fermentação. Semina: Ciências Agrárias, 30, 761-770. http://dx.doi.org/10.5433/1679- 0359.2009v30n4p761

Araújo, L. R., Alves, E. U., Rodrigues, C. M., \& Rodrigues, A. A. M. (2015). Emergência e crescimento inicial de plântulas de Eugenia jambolana Lam. após remoção da polpa. Ciência Rural, 45, 14-18. http://dx.doi.org/10.1590/0103-8478cr20120625

Batista, P. F., Maia, S. S. S., Coelho, M. F. B., Benedito, C. P., \& Guimarães, I. P. (2011). Propagação vegetativa de romã em diferentes substratos. Revista Verde de Agroecologia e Desenvolvimento Sustentável, 6(4), 96-100. http://dx.doi.org/10.18378/rvads.v12i1.4070

Brasil. (2009). Ministério da Agricultura, Pecuária e Abastecimento. Regras para análise de sementes (p. 395). Brasília: Secretaria de Defesa Agropecuária.

Cardoso, G. D., Tavares, J. C., Ferreira, R. L. F., Câmara, F. A. A., \& Carmo, G. A. (2001). Desenvolvimento de mudas de maracujazeiro-amarelo obtidas de sementes extraídas por fermentação. Revista Brasileira de Fruticultura, 23(3), 639-642. http://dx.doi.org/10.1590/S0100-29452001000300039

Carvalho, N. M., \& Nakagawa, J. (2012) Sementes: ciência, tecnologia e produção (5th ed., p. 590). Jaboticabal: FUNEP.

Ferreira, A. B. H. (2004). Novo dicionário Aurélio da língua portuguesa (3rd ed., p. 2120). Curitiba: Positivo.

Freitas, S. J., Barroso, D. G., Silva, R. F., Martins, V. H. C. R., Freitas, M. D. S., \& Ferreira, P. R. (2011). Métodos de remoção da sarcotesta na germinação de sementes de jaracatiá. Revista Árvore, 35(1), 91-96. http://dx.doi.org/10.1590/S0100-67622011000100011

Gokturk, A., Olmez, Z., Karasah, B., \& Surat, H. (2012). Effects of cold stratification and sulphuric acid pre-treatments on germination of pomegranate (Punica granatum L.) seeds in greenhouse and laboratory conditions. Scientific Research and Essays, 7(25), 2225-2229. http://dx.doi.org/10.3923/ajps.2007.427.430

Kanwar, K., Joseph, J., \& Deepika, R. (2010). Comparison of in vitro regeneration pathways in Punica granatum L. Plant Cell Tissue Organ Culture, 100, 199-207. https://doi.org/10.1007/s11240-009-9637-4

Lopes, K. P., Bruno, R. L. A., Bruno, G. B., \& Azeredo, G. A. A. (2001). Comportamento de sementes de romã (Punica granatum L.) submetidas à fermentação e secagem. Revista Brasileira de Fruticultura, 23(2), 369-372. http://dx.doi.org/10.1007/s11240-009-9637-4

Maguire, J. D. (1962). Speed of germination aid in selection and evaluation for seedling emergence and vigor. Crop Science, 2(2), 176-177. https://doi.org/10.2135/cropsci1962.0011183X000200020033x

Marcos Filho, J. (2015). Fisiologia de sementes de plantas cultivadas (3rd ed., p. 659). Londrina: ABRATES. 
Martins, C. M., Vasconcellos, M. A. S., Rossetto, C. A. V., \& Carvalho, M. G. (2010). Prospecção fitoquímica do arilo de sementes de maracujá-amarelo e influência em germinação de sementes. Ciência Rural, 40(9), 1934-1940. http://dx.doi.org/10.1590/S0103-84782010000900013

Martins, M. R., Reis, M. C., Mendes Neto, J. A., Gusmão, L. L., \& Gomes, J. J. A. (2006). Influência de diferentes métodos de remoção do arilo na germinação de sementes de maracujazeiro-amarelo (Passiflora edulis sims f. flavicarpa Deg.). Revista da Faculdade de Zootecnia, Veterinária e Agronomia, 13, 117-128.

Materechera, S. A., \& Seeiso, T. M. (2013). Seed treatment to improve water imbibition and germination of pomegranate (Punica granatum). Acta Horticulturae, 979, 713-721. http://dx.doi.org/10.17660/ActaHortic. 2013.979.80

Melo, A. P. C., \& Seleguini, A. (2013). Estádio de maturação de frutos e remoção física da sarcotesta na produção de mudas de mamão. Comunicata Scientiae, 4, 20-25.

Olmez, Z., Temel, F., Gokturk, A., \& Yahyaoglu, Z. (2007). Effects of sulphuric acid and cold stratification pre-treatments on germination of pomegranate (Punica granatum L.) seeds. Asian Journal of Plant Sciences, 6(2), 427-430. http://dx.doi.org/10.3923/ajps.2007.427.430

Osipi, E. A. F., Lima, C. B., \& Cossa, C. A. (2011). Influence of methods of aryl remotion on physiology and quality of Passiflora alata. Revista Brasileira de Fruticultura, 33, 680-685. http://dx.doi.org/10.1590/ S0100-29452011000500095

Pereira, K. J. C., \& Dias, D. C. F. (2000). Germinação e vigor de sementes de maracujá-amarelo (Passiflora edulis Sims f. flavicarpa Deg.) submetidas a diferentes métodos de remoção da mucilagem. Revista Brasileira de Fruticultura, 22(1), 288-291. http://dx.doi.org/10.17801/0101-3122/rbs.v22n1p288-291

Santos-Moura, S. S., Alves, E. U., Galindo, E. A., Moura, M. F., \& Melo, P. A. F. R. (2014). Qualidade fisiológica de sementes de Crataeva tapia L. submetidas a diferentes métodos de extração da mucilagem. Revista Brasileira de Fruticultura, 36, 686-692. http://dx.doi.org/10.1590/0100-2945-133/13

São José, A. R., \& Nakagawa, J. (1987). Efeitos da fermentação e secagem na germinação de sementes de maracujá-amarelo. Revista Brasileira de Sementes, 9(2), 35-43. http://dx.doi.org/10.17801/0101-3122/ rbs.v9n2p35-43

Silva, L. M. M. (2013). Protocolos de criopreservação de sementes de romã e juá (Doctoral dissertation, Universidade Federal de Campina Grande, Paraíba, Brazil).

Silva, R. F. (2000). Extração de sementes de frutos carnosos. In N. M. Carvalho, \& J. Nakagawa (Eds.), Sementes: Ciência, tecnologia e produção (4th ed., pp. 458-484). Jaboticabal: Funep.

Werkman, C., Granato, D. C., Kerbauy, W. D., Sampaio, F. C., Brandão, A. A. H., \& Rode, S. M. (2008). Aplicações terapêuticas da Punica granatum L. (Romã). Revista Brasileira de Plantas Medicinais, 10(3), 104-111.

\section{Copyrights}

Copyright for this article is retained by the author(s), with first publication rights granted to the journal.

This is an open-access article distributed under the terms and conditions of the Creative Commons Attribution license (http://creativecommons.org/licenses/by/4.0/). 